\title{
Proses Migrasi Cloud Computing dari Lingkungan Amazon EC2 ke VMWARE
}

\author{
Jauharul Mafakhiri ${ }^{1}$, Rizal Fathoni Aji² \\ ${ }^{1}$ Magister Teknik Informatika Universitas AMIKOM Yogyakarta \\ Jln. Ring Road Utara, Condong Catur, Sleman, Yogyakarta, Indonesia 55283 \\ 1jauhmf@gmail.com \\ ${ }^{2}$ Fakultas Ilmu Komputer Universitas Indonesia \\ Kampus UI Depok, Jawa Barat, Indonesia 16424 \\ ${ }^{2}$ rizal@cs.ui.ac.id (penulis korespondensi)
}

\begin{abstract}
Intisari- Permasalahan pada penelitian ini adalah mengenai pengujian virtual machine di tingkat fungsionalitas aplikasi pada lingkungan komputasi awan di antara dua cloud provider IaaS (Infrastructure as a Service). Tujuan dari pengujian fungsionalitas ini adalah untuk mengetahui tingkat interoperabilitas aplikasi dalam sistem virtual machine yang berpindah dari sebuah cloud provider ke cloud provider lain, yaitu migrasi dari Amazon EC2 ke VMWARE. Peneliti memiliki ketertarikan mengenai pengujian migrasi ini sebab perkembangan Internet menjadi semakin pesat, dan diiringi dengan meningkatnya jumlah aplikasi yang memanfaatkan teknologi komputasi awan itu, sementara kemampuan proses bisnis suatu aplikasi semakin bertambah, fitur layanan yang ditawarkan para pihak cloud provider menjadi semakin baik (dari sisi harga menjadi lebih murah, performansi sistem menjadi lebih tinggi, sistem menjadi lebih handal, pemanfaatan kecanggihan teknologi security terbaru, maupun Service Level Agreement (SLA) menjadi lebih baik), maka memungkinkan untuk berpindah layanan ke cloud provider lain, namun di sisi praktik sering terjadi kegagalan fungsionalitas aplikasi dalam proses migrasi ke sistem cloud yang lain, yang antara lain disebabkan oleh masalah ketergantungan terhadap penyedia layanan komputasi awan (vendor lock-in). Masalah ketergantungan ini muncul disebabkan oleh jumlah cloud provider semakin bertanbah banyak dan mempunyai standar tersendiri dalam pembangunan sistemnya, sehingga dapat mengakibatkan kemampuan migrasi antar cloud itu dapat memiliki keterbatasan untuk hal-hal tertentu. Dengan 28 test case pengujian atas fitur-fitur pada aplikasi website ujian online yang diuji pada penelitian ini, diperoleh hasil tingkat interoperabilitas migrasi dari Amazon EC2 ke VMWARE memiliki nilai sebesar 46.43\%.
\end{abstract}

Kata kunci - pengujian, fungsionalitas, komputasi, awan, migrasi, interoperabilitas.

Abstract - The problem in this study is about testing virtual machines at the level of application functionality in the cloud computing environment between two IaaS cloud providers (Infrastructure as a Service). The purpose of this functionality testing is to determine the level of interoperability of applications in a virtual machine system that moves from a cloud provider to another cloud provider, namely migration from Amazon EC2 to VMWARE. Researchers have an interest in testing this migration because the development of the Internet is becoming increasingly rapid, and is accompanied by an increasing number of applications that utilize cloud computing technology, while the ability of business processes to increase applications, service features offered by cloud providers are getting better (from the side the price becomes cheaper, the system performance becomes higher, the system becomes more reliable, the utilization of the latest sophistication of security technology, and the Service Level Agreement (SLA) becomes better), it is possible to switch services to other cloud providers, but on the practice side often failure of application functionality in the process of migrating to other cloud systems, which among others is caused by a problem of dependence on providers of cloud computing services (vendor lock-in). This dependency problem arises due to the number of cloud providers increasingly bertanbah many and has its own standards in the construction of the system, so that it can lead to inter-cloud migration capabilities that can have limitations for certain things. With 28 test case tests of features on the online exam website application tested in this study, the results of the level of interoperability of migration from Amazon EC2 to VMWARE obtained a value of $46.43 \%$.

Keywords — testing, functionality, computing, cloud, migration, interoperability.

\section{Pendahuluan}

Cloud computing merupakan suatu cara baru dalam memaksimalkan pemanfaatan teknologi informasi, yang menawarkan skalabilitas untuk proses bisnis organisasi di suatu institusi. Perkembangan teknologi memungkinkan suatu institusi memperluas atau mengurangi fasilitas komputasi mereka sangat cepat. Pemerintah Indonesia melalui Kementrian Komunikasi dan Informatika menilai bahwa penerapan cloud computing sangat relevan dengan kondisi Indonesia saat ini. Oleh karena itu, sektor device, network, dan application menjadi faktor penting untuk mendorong penggunaan komputasi awan. Virtual machine merupakan bagian dari cloud computing, khususnya dalam layanan Infrastructure as a Service ( IaaS).

Migrasi sistem virtual machine dapat dimungkinkan dalam layanan IaaS [1]. Dalam proses migrasi IaaS, konversi image virtual machine dari satu sistem ke sistem lain tidak menjamin keberhasilan proses migrasi. Terdapat kecenderungan beberapa parameter seperti konfigurasi central processing unit, random access memory, jaringan, serta struktur aplikasi dan data yang mungkin bisa berubah dalam proses migrasi. Masalah lain yang bisa terjadi adalah ketika aplikasi yang 
berjalan telah terintegrasi secara kompleks di sistem lama sehingga sistem sulit melakukan migrasi di sistem baru [2].

Karena beragamnya penyedia layanan cloud computing mengakibatkan muncul masalah berupa ketergantungan terhadap penyedia layanan cloud computing. Permasalahan ketergantungan ini merupakan suatu keadaan di mana pengguna suatu produk bergantung pada satu provider dan tidak dapat berpindah ke provider lain. Jika bisa berpindah, maka butuh biaya yang besar dan waktu yang lama [3]. Setiap cloud provider memiliki format tersendiri dalam membangun produk layanan yang dimiliki, sehingga menyebabkan terbatasnya kemampuan sistem migrasi antar-cloud. Kemampuan interoperabilitas menjadi faktor kunci dalam proses migrasi atau perpindahan dari satu sistem ke sistem lainnya di lingkungan cloud computing. Interoperabilitas cloud merupakan cara untuk memudahkan migrasi dan mengintegrasikan aplikasi dan data diantara penyedia layanan cloud computing [4]. Cloud computing dapat didefinisikan sebagai kumpulan aplikasi dan layanan yang berjalan dan beroperasi dalam jaringan terdistribusi atau tersebar dengan memanfaatkan sumber daya virtual dan standar Internet [5]. Sejarah cloud computing berawal dari layanan baru perusahaan telekomunikasi yang menawarkan produk virtual private network yang sebelumnya merupakan sirkuit data yang bersifat point-to-point [6]. Virtualisasi merupakan teknologi utama yang memungkinkan munculnya paradigma cloud computing. Teknik virtualisasi memungkinkan beberapa sistem operasi berjalan secara simultan di dalam satu mesin fisik [7]. Virtualisasi memisahkan aplikasi, desktop, mesin, jaringan, data, dan layanan dari sumber daya fisik [8]. Prinsip virtualisasi secara ringkas dapat dilihat pada Gambar 1.

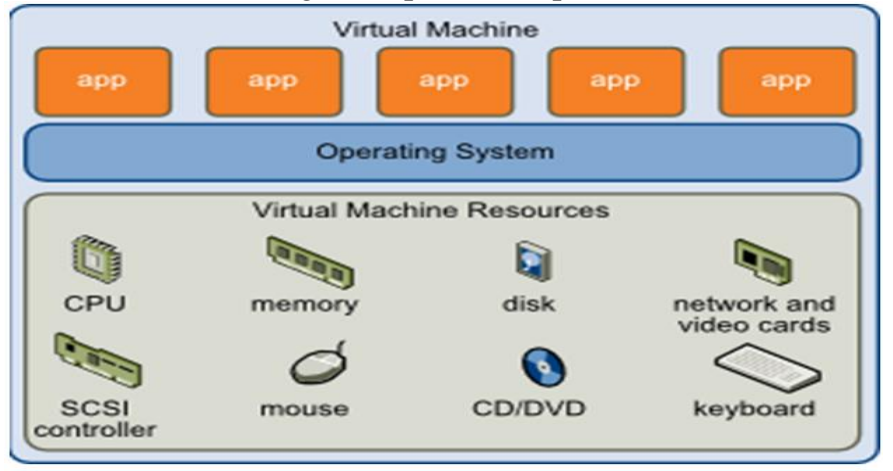

Gambar 1. Prinsip Virtualisasi [8]

Terdapat definisi dari tiga tipe operasi migrasi untuk virtual machine [9], yaitu:

A. Level 1: Virtual machine hanya berjalan di produk virtualisasi/arsitektur CPU/virtual hardware tertentu.

Migrasi level 1 setara dengan operasi Suspend di sistem awal/sumber dan operasi Resume di sistem tujuan/target. Mekanisme Live Migration dimungkinkan berjalan pada Level 1 ini.

B. Level 2: Virtual machine berjalan di keluarga perangkat virtual yang lebih spesifik.
Migrasi level 2 ini setara dengan operasi Shut-down di sistem sumber diikuti dengan operasi Reboot di sistem target. Migrasi dengan berbeda hypervisor dapat dimungkinkan berjalan pada level ini.

C. Level 3: Virtual machine dapat berjalan di banyak keluarga perangkat virtual.

Level ini merupakan framework paling fleksibel untuk migrasi virtual machine, tetapi membutuhkan pembangunan yang terintegrasi dan teknologi yang digunakan belum familiar.

Dalam proses migrasi dari satu sistem ke sistem yang lain pada lingkungan cloud computing, kemampuan interoperabilitas menjadi faktor yang penting. Interoperabilitas cloud mengacu pada kemudahan migrasi dan integrasi aplikasi, data, dan beban kerja diantara penyedia layanan cloud [4]. Selain itu dengan adanya inkompatibilitas standar di antara penyedia cloud platform provider mengakibatkan migrasi aplikasi dari suatu provider ke provider lain masih menjadi proses yang sulit [10]. Maksud dari penelitian ini adalah menyajikan metode yang dipakai untuk mengukur tingkat interoperabilitas fungsionalitas aplikasi ketika suatu migrasi dilakukan di antara dua provider cloud IaaS yang berbeda, dengan tujuan untuk memberikan referensi metode pengujian interoperabilitas migrasi sistem antar-cloud yang lebih spesifik ke fungsionalitas aplikasi, sehingga dapat diimplementasikan di suatu institusi pendidikan sesuai proses bisnis yang sedang berjalan.

\section{Metodologi PENELITIAN}

Penelitian ini dilakukan dengan menggunakan metodologi seperti bagan yang ditunjukkan pada Gambar 2 .

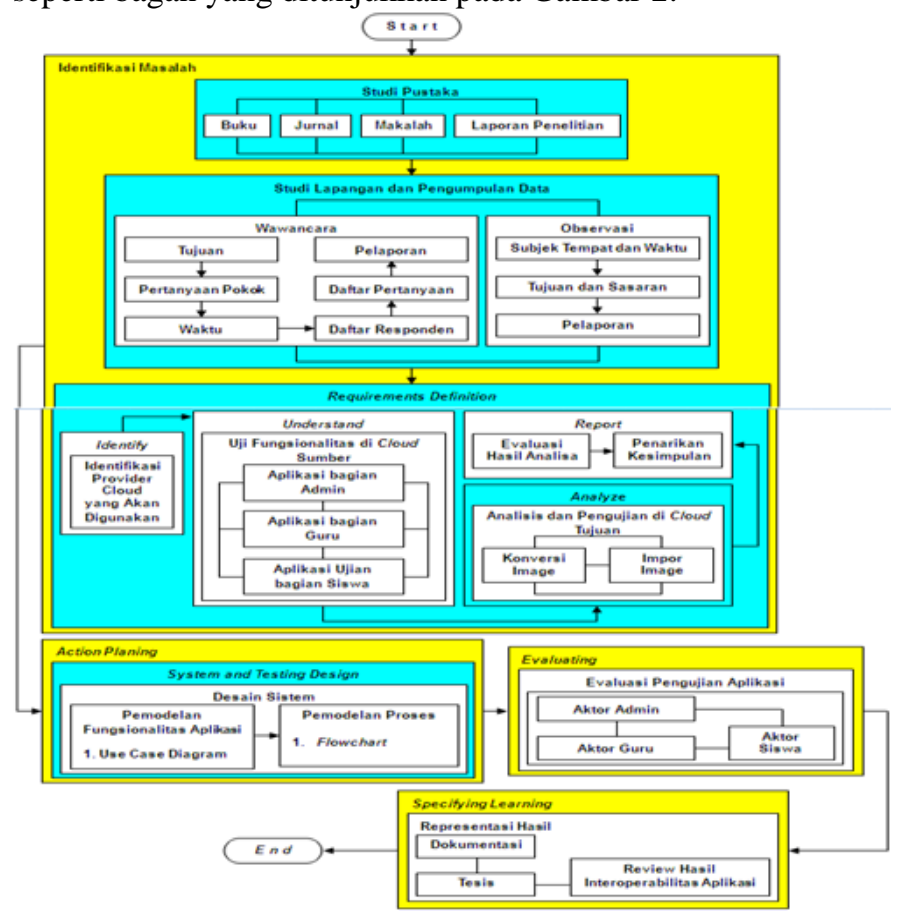

Gambar 2. Metodologi Penelitian 
Tahapan-tahapan metodologi di Gambar 2 dapat dijelaskan sebagai berikut:

\section{A. Melakukan Identifikasi Masalah dan Studi Pustaka}

Di tahap ini peneliti membuat fokus permasalahan yang dibahas pada penelitian ini, yaitu untuk melakukan pengujian interoperabilitas migrasi sistem antar cloud. Peneliti juga melakukan studi pustaka dengan cara mempelajari buku, file, ataupun dokumen yang diperlukan, seperti Standar Operasional Prosedur (SOP), panduan dan instruksi kerja, Minutes of Meeting (MOM), dan bentuk yang lain yang ada di sebuah institusi.

\section{B. Melakukan Studi Lapangan dan Pengumpulan Data}

Pengumpulan data dengan studi lapangan dilakukan dengan cara melakukan tanya jawab (wawancara) kepada pimpinan institusi, penanggung jawab atau pihak yang diberikan wewenang oleh pimpinan institusi terkait dengan penelitian ini, dan melakukan pengamatan secara langsung (observasi) di saat Admin, Guru, dan Siswa SMK Negeri I Plosoklaten Kediri Jawa Timur sedang mengoperasikan aplikasi ujian/ulangan online, ketika dilakukan migrasi terhadap sistem itu aplikasi itu.

\section{Requirements Definition}

Beberapa hal yang peneliti lakukan di tahap ini adalah:

1. Mengidentifikasi provider cloud computing yang akan digunakan dalam migrasi data dan pengujian fungsionalitas aplikasi yang dites.

2. Perlu memahami tahap-tahap pengujian fungsionalitas aplikasi untuk tiap-tiap aktor yang berperan sebagai pemakai sistem, yang mana pengujian ini dilakukan di cloud sumber.

3. Mengamati hasil analisis dan pengujian fungsionalitas aplikasi di cloud tujuan, yaitu mengenai konversi maupun dan impor image.

4. Melakukan evaluasi dari hasil analisis dan melakukan penarikan kesimpulan. Item-item aktivitas dan detail aktivitas dapat dilihat di bagian Hasil dan Pembahasan.

\section{System and Testing Design}

Use case diagram dipakai untuk membuat pemodelan fungsionalitas aplikasi, dan beberapa flowchart untuk membuat pemodelan proses dari subsistem aplikasi yang dijalankan oleh aktor Admin, Guru, dan Siswa.

\section{E. Evaluating}

Di tahap ini dilakukan evaluasi terhadap hasil pengujian fungsionalitas aplikasi yang telah dilakukan di tahap sebelumnya. Tujuan evaluasi ini adalah untuk mengetahui seberapa besar tingkat interoperabilitas dari migrasi Amazon EC2 ke VMWARE.

\section{F. Representasi Hasil}

Tahap ini merupakan langkah terakhir penelitian berupa penyusunan laporan mengenai hasil penelitian Tesis dengan judul Evaluasi Pengujian Fungsionalitas Aplikasi pada
Migrasi Virtual Machine dalam Lingkungan Cloud Computing. Pembuatan laporan ini diharapkan dapat memberikan informasi mengenai layanan terbaik dalam migrasi di antara beberapa lingkungan cloud IaaS, dan memberikan referensi metode pengujian interoperabilitas migrasi sistem antar cloud yang lebih spesifik ke fungsi aplikasi itu, sehingga sistem aplikasi dapat diimplementasikan di institusi pendidikan sesuai proses bisnis yang sedang berjalan.

\section{HASIL DAN PEMBAHASAN}

\section{A. Skenario Migrasi Sistem}

Tahapan yang dilakukan pada infrastruktur migrasi cloud dari Amazon EC2 ke VMWARE ini meliputi:

a. Melakukan pengujian fungsionalitas aplikasi di server fisik,

b. Migrasi image dari server fisik ke server Amazon EC2,

c. Melakukan pengujian fungsionalitas aplikasi,

d. Migrasi image dari server Amazon EC2 ke VMWARE, dan

e. Melakukan pengujian fungsionalitas aplikasi di server VMWARE.

Skenario dari migrasi ini ditunjukkan pada Gambar 3.

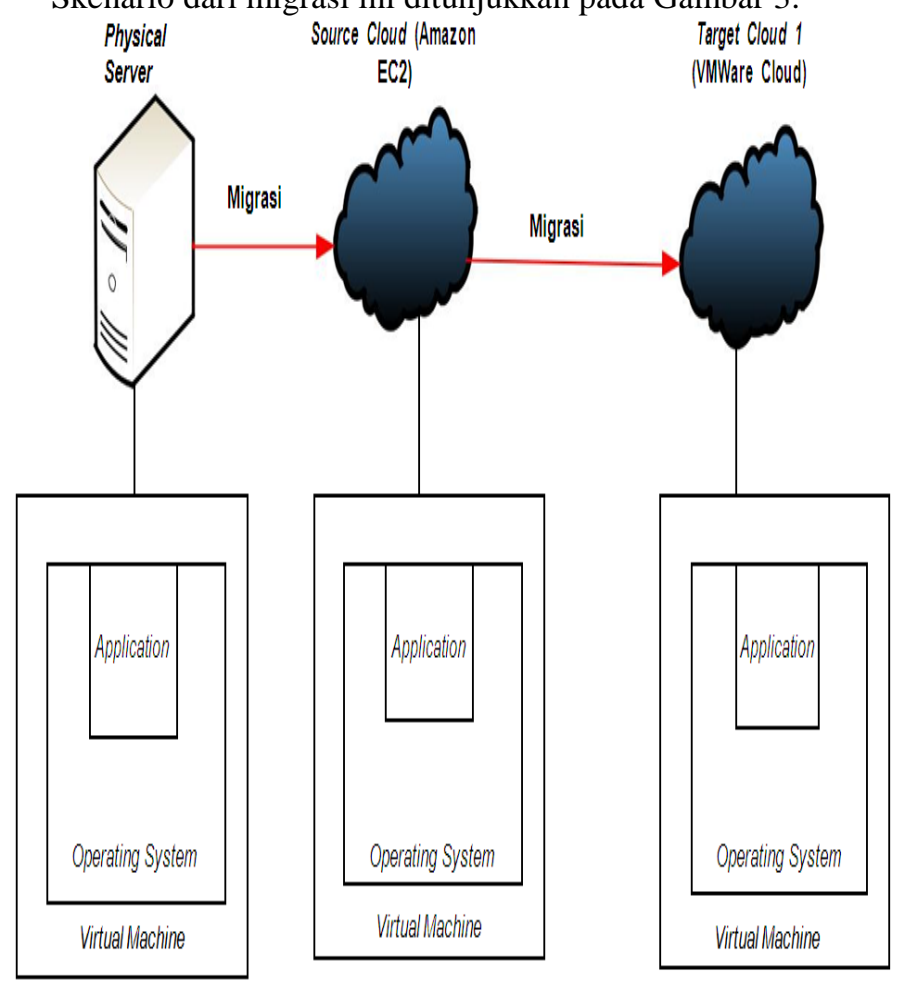

Gambar 3. Skenario Migrasi

\section{B. Sistem Ujian/Ulangan Online Berbasis Website}

Penelitian ini menguji tingkat interoperabilitas sistem ujian/ulangan online yang merupakan sebuah website milik SMK Negeri 1 Plosoklaten Kediri Jawa Timur. Use case diagram dan beberapa flowchart dipakai untuk mempermudah dalam menentukan fungsionalitas aplikasi apa saja yang akan diuji. 
Use case diagram pada Gambar 4 menggambarkan fungsifungsi yang terdapat pada sistem ujian/ulangan online itu dan siapa saja yang berhak menggunakan fungsi-fungsi tersebut.

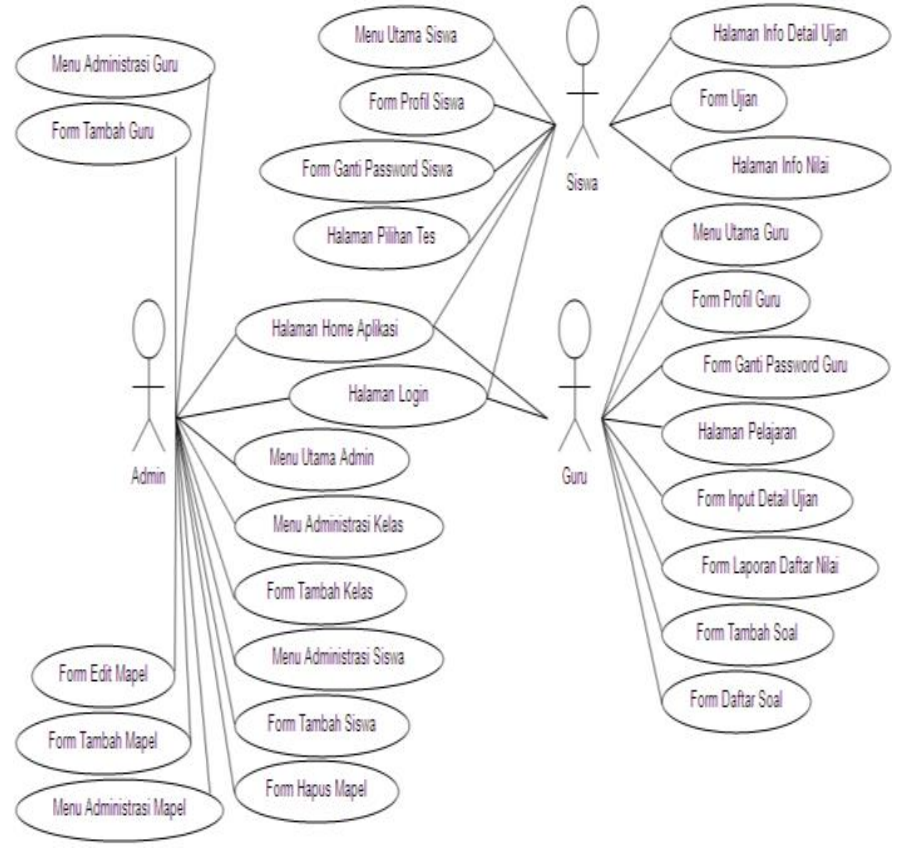

Gambar 4. Use Case Diagram Sistem Ujian/Ulangan Online

Gambar 5 menunjukkan logika proses dari login user, sebagai berikut:
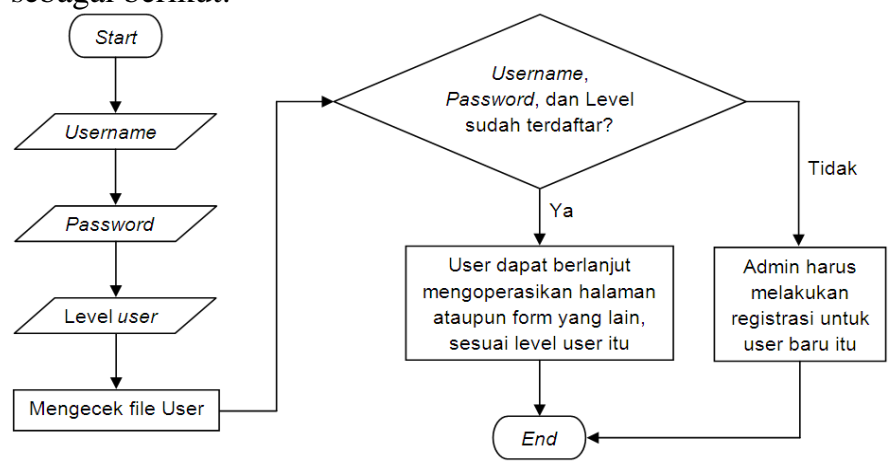

Gambar 5. Flowchart Login

Kegiatan aktor Siswa dalam mengikuti ujian/ulangan secara online memiliki logika proses seperti yang ditunjukkan melalui flowchart pada Gambar 6.

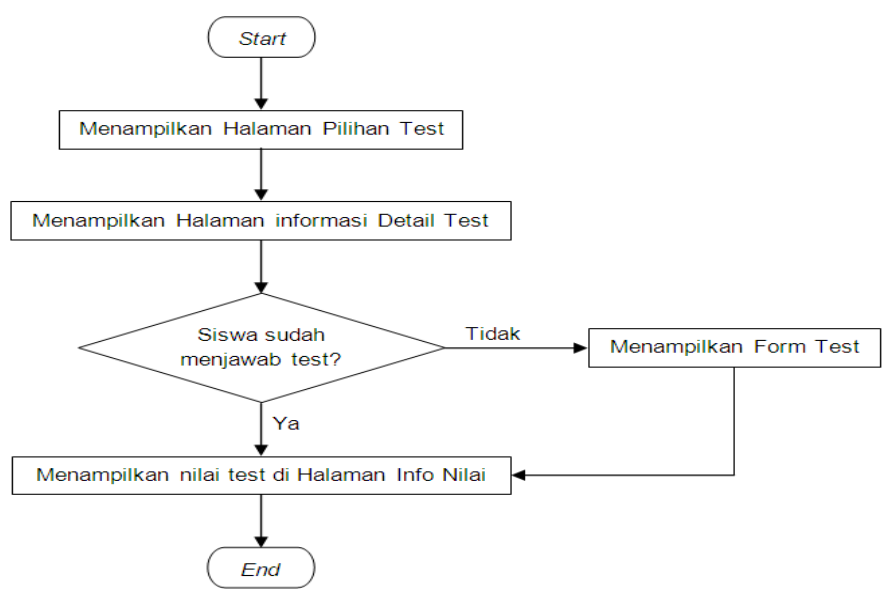

Gambar 6. Flowchart Halaman Informasi Detail Ujian/ulangan Siswa

Aktivitas aktor Guru di dalam sistem dapat digambarkan dengan flowchart seperti pada Gambar 7 di bawah ini.

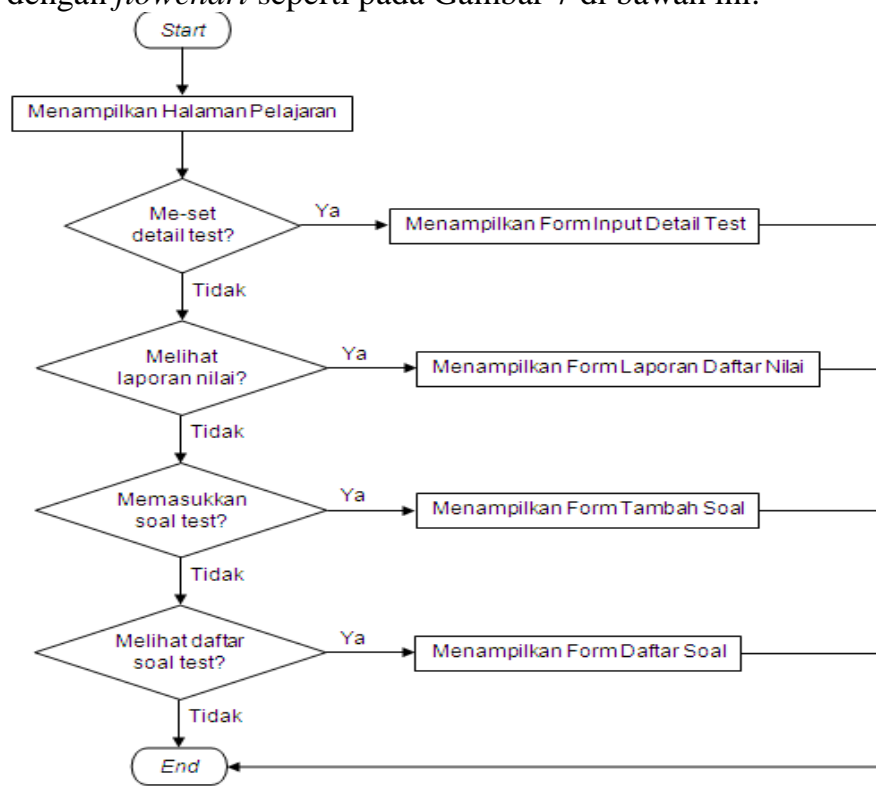

Gambar 7. Flowchart Aktivitas dari Aktor Guru

Aktivitas aktor Admin di dalam sistem dapat digambarkan dengan flowchart seperti pada Gambar 8 di bawah ini. 


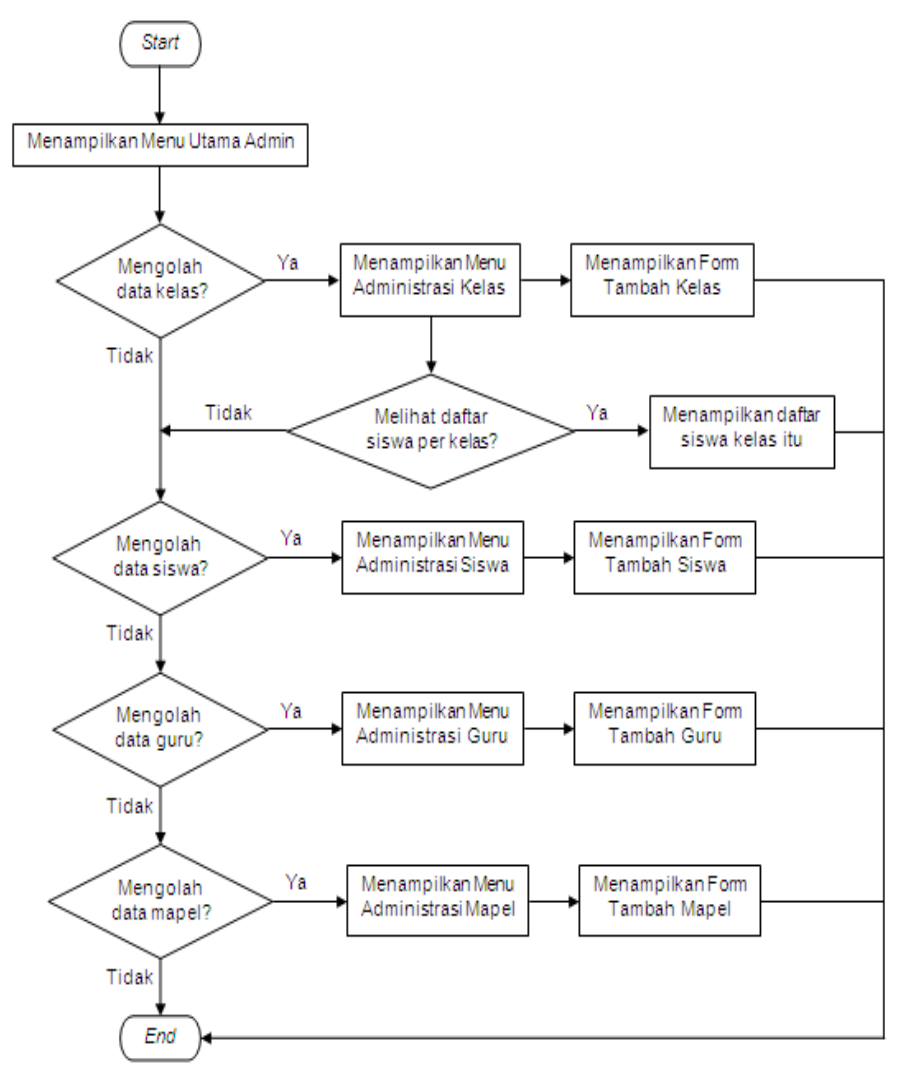

Gambar 8. Flowchart Aktivitas dari Aktor Admin

\section{Migrasi Amazon EC2 ke VMWARE}

Perintah impor virtual machine image di server Amazon EC2 adalah:

aws ec2 import-image --cli-input-json "\{ \"Description\": \"Server Lokal OVA\", $\backslash$ "DiskContainers \": [ \{ \"Description\": \"Server Lokal OVA \", \"UserBucket\": \{ \"S3Bucket\": $\backslash$ "Dummyimport \", \"S3Key \" : \"server-ubuntulokal.ova \" \} \}

Perintah ekspor image dari server Amazon EC2 ke server VMWARE adalah:

ec2-create-instance-export-task i-256d65e6 -e VMWARE -f VMDK - c OVA -b Dummytesis

Hasil pengujian migrasi image virtual machine Amazon EC2 ke VMWARE Cloud diperinci pada Tabel I.

$$
\text { TABEL I }
$$

Hasil Pengujian MigRasi Image ViRTUal MaChine Amazon EC2 KE VMWARE

\begin{tabular}{lll}
\hline \multicolumn{1}{c}{ Jenis Pengujian } & Parameter yang Diuji & Hasil \\
\hline Migrasi server fisik ke Amazon & Booting & Berhasil \\
\cline { 2 - 3 } EC2 & Login & Berhasil \\
\hline Migrasi server Amazon EC2 ke & Booting & Berhasil \\
\cline { 2 - 3 } VMWARE Cloud & Login & Berhasil \\
\hline
\end{tabular}

Tabel II menunjukkan hasil pengujian fungsionalitas aplikasi setelah proses migrasi aplikasi mulai dari server fisik ke server Amazon EC2, kemudian dilanjutkan dari Amazon EC2 ke server VMWARE terdapat error/defect software yang termasuk ke dalam klasifikasi minor defect yaitu ketika para aktor (Admin, Guru, dan Siswa) mengakses beberapa halaman, namun sistem tidak dapat menampilkan banner website. TABEL II

HASIL PENGUJIAN FungSIONALITAS APLIKASI DARI AMAZON EC2 KE VMWARE

\begin{tabular}{lll}
\hline \multirow{2}{*}{ Aktivitas } & \multicolumn{2}{c}{ Hasil Pengujian Server Fisik } \\
\cline { 2 - 3 } & Defect Major & Defect Minor \\
\hline Halaman Home Aplikasi & Tidak ada & Tidak ada \\
\hline Halaman Login & Tidak ada & Tidak ada \\
\hline Menu Utama Siswa & Tidak ada & Tidak ada \\
\hline Form Profil Siswa & Tidak ada & Tidak ada \\
\hline Form Ganti Password Siswa & Tidak ada & Tidak ada \\
\hline Halaman Pilihan Test & Tidak ada & Tidak ada \\
\hline Halaman Informasi Detail Test & Tidak ada & Tidak ada \\
\hline Form Test & Tidak ada & Tidak ada \\
\hline Halaman Info Nilai & Tidak ada & Tidak ada \\
\hline Menu Utama Guru & Tidak ada & Tidak ada \\
\hline Form Profil Guru & Tidak ada & Tidak ada \\
\hline Form Ganti Password Guru & Tidak ada & Tidak ada \\
\hline Halaman Pelajaran & Tidak ada & Tidak ada \\
\hline Form Input Detail Test & Tidak ada & Tidak ada \\
\hline Form Laporan Daftar Nilai & Tidak ada & Tidak ada \\
\hline Form Tambah Soal & Tidak ada & Tidak ada \\
\hline Form Daftar Soal & Tidak ada & Tidak ada \\
\hline Menu Utama Admin & Tidak ada & Tidak ada \\
\hline Menu Administrasi Kelas & Tidak ada & Tidak ada \\
\hline Form Tambah Kelas & Tidak ada & Tidak ada \\
\hline Menu Administrasi Siswa & Tidak ada & Tidak ada \\
\hline Form Tambah Siswa & Tidak ada & Tidak ada \\
\hline Menu Administrasi Guru & Tidak ada & Tidak ada \\
\hline Form Tambah Guru & Tidak ada & Tidak ada \\
\hline Menu Administrasi Mapel & Tidak ada & Tidak ada \\
\hline Form Tambah Mapel & Tidak ada & Tidak ada \\
\hline Form Hapus Mapel & Tidak ada & Tidak ada \\
\hline & Tidak ada & Tidak ada \\
\hline
\end{tabular}

TABEL II

(LANJUTAN)

\begin{tabular}{lll}
\hline \multicolumn{1}{c}{ Aktivitas } & \multicolumn{2}{c}{ Hasil Pengujian Server Amazon EC2 } \\
\cline { 2 - 3 } & Defect Major & Defect Minor \\
\hline Halaman Home Aplikasi & Tidak ada & Tidak ada \\
\hline Halaman Login & Tidak ada & Tidak ada \\
\hline Menu Utama Siswa & Tidak ada & Tidak ada \\
\hline Form Profil Siswa & Tidak ada & Tidak ada \\
\hline Form Ganti Password Siswa & Tidak ada & Tidak ada \\
\hline Halaman Pilihan Test & Tidak ada & Tidak ada \\
\hline Halaman Informasi Detail Test & Tidak ada & Tidak ada \\
\hline Form Test & Tidak ada & Tidak ada \\
\hline Halaman Info Nilai & Tidak ada & Tidak ada \\
\hline Menu Utama Guru & Tidak ada & Tidak ada \\
\hline Form Profil Guru & Tidak ada & Tidak ada \\
\hline Form Ganti Password Guru & Tidak ada & Tidak ada \\
\hline Halaman Pelajaran & Tidak ada & Tidak ada \\
\hline Form Input Detail Test & Tidak ada & Tidak ada \\
\hline Form Laporan Daftar Nilai & Tidak ada & Tidak ada \\
\hline Form Tambah Soal & Tidak ada & Tidak ada \\
\hline Form Daftar Soal & Tidak ada & Tidak ada \\
\hline Menu Utama Admin & Tidak ada & Tidak ada \\
\hline Menu Administrasi Kelas & Tidak ada & Tidak ada \\
\hline Form Tambah Kelas & Tidak ada & Tidak ada \\
\hline Menu Administrasi Siswa & Tidak ada & Tidak ada \\
\hline Form Tambah Siswa & Tidak ada & Tidak ada \\
\hline Menu Administrasi Guru & Tidak ada & Tidak ada \\
\hline Form Tambah Guru & Tidak ada & Tidak ada \\
\hline
\end{tabular}




\begin{tabular}{lll}
\hline Menu Administrasi Mapel & Tidak ada & Tidak ada \\
\hline Form Tambah Mapel & Tidak ada & Tidak ada \\
\hline Form Edit Mapel & Tidak ada & Tidak ada \\
\hline Form Hapus Mapel & Tidak ada & Tidak ada \\
\hline
\end{tabular}

TABEL II

(LANJUTAN)

\begin{tabular}{|c|c|c|}
\hline \multirow[t]{2}{*}{ Aktivitas } & \multicolumn{2}{|c|}{ Hasil Pengujian Server VMWARE } \\
\hline & Defect Major & Defect Minor \\
\hline Halaman Home Aplikasi & Tidak ada & Banner website hilang \\
\hline Halaman Login & Tidak ada & Banner website hilang \\
\hline Menu Utama Siswa & Tidak ada & Banner website hilang \\
\hline Form Profil Siswa & Tidak ada & Tidak ada \\
\hline Form Ganti Password Siswa & Tidak ada & Tidak ada \\
\hline Halaman Pilihan Test & Tidak ada & Banner website hilang \\
\hline Halaman Informasi Detail Test & Tidak ada & Banner website hilang \\
\hline Form Test & Tidak ada & Tidak ada \\
\hline Halaman Info Nilai & Tidak ada & Banner website hilang \\
\hline Menu Utama Guru & Tidak ada & Banner website hilang \\
\hline Form Profil Guru & Tidak ada & Tidak ada \\
\hline Form Ganti Password Guru & Tidak ada & Tidak ada \\
\hline Halaman Pelajaran & Tidak ada & Banner website hilang \\
\hline Form Input Detail Test & Tidak ada & Tidak ada \\
\hline Form Laporan Daftar Nilai & Tidak ada & Tidak ada \\
\hline Form Tambah Soal & Tidak ada & Tidak ada \\
\hline Form Daftar Soal & Tidak ada & Tidak ada \\
\hline Menu Utama Admin & Tidak ada & Banner website hilang \\
\hline Menu Administrasi Kelas & Tidak ada & Banner website hilang \\
\hline Form Tambah Kelas & Tidak ada & Tidak ada \\
\hline Menu Administrasi Siswa & Tidak ada & Banner website hilang \\
\hline Form Tambah Siswa & Tidak ada & Tidak ada \\
\hline Menu Administrasi Guru & Tidak ada & Banner website hilang \\
\hline Form Tambah Guru & Tidak ada & Tidak ada \\
\hline Menu Administrasi Mapel & Tidak ada & Banner website hilang \\
\hline Form Tambah Mapel & Tidak ada & Tidak ada \\
\hline Form Edit Mapel & Tidak ada & Tidak ada \\
\hline Form Hapus Mapel & Tidak ada & Tidak ada \\
\hline
\end{tabular}

Ketika Amazon Machine Image (AMI) hasil import sudah terbentuk dan AMI siap untuk diubah menjadi virtual machine baru di server Amazon EC2, konfigurasi virtual machine asli seperti konfigurasi hardware (meliputi memory, hardisk, CPU) dapat berubah menyesuaikan dengan konfigurasi pilihan yang telah disediakan oleh Amazon EC2, berdasarkan pengujian perubahan konfigurasi hardware ini hanya berpengaruh pada performansi aplikasi saja, dan belum ditemukan kasus untuk fungsionalitas aplikasi dalam penelitian ini. Seperti pada 9 dibawah ini, terlihat bahwa saat sistem masih di server fisik, besar konfigurasi memori mencapai $2048 \mathrm{MB}$.

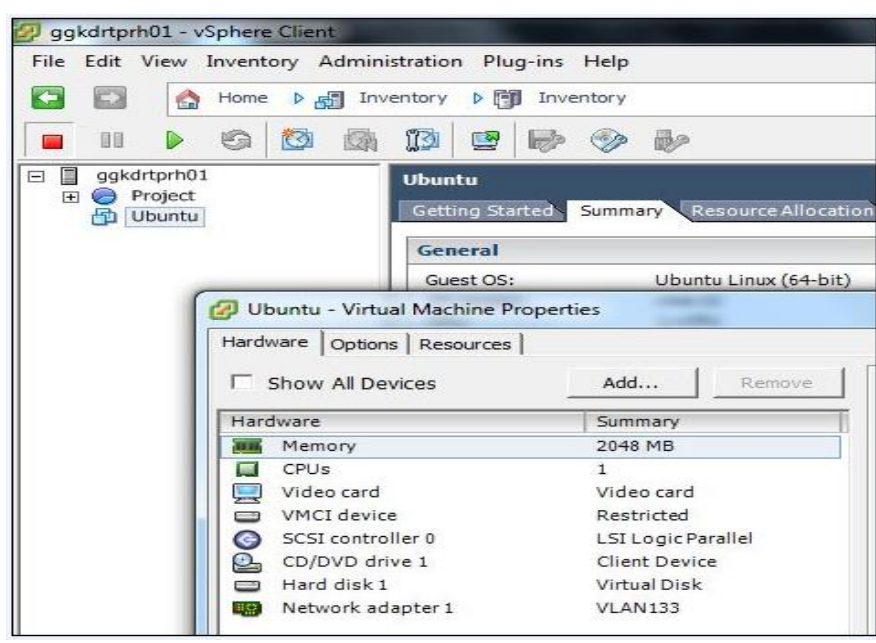

Gambar 9. Konfigurasi Hardware pada Physical Server

Kemudian Gambar 10 menunjukkan bahwa konfigurasi pembuatan virtual machine baru dari image server fisik mengalami perubahan besar memory menjadi 1 GB.

Step 2: Choose an Instance Type

Amazon EC2 provides a wide selection of instance types optimized to fil different use cases. instances are vitt and networking capacily, and give you the flexibility to choose the appropriate mix of resources for your applici

\section{Filter by: All instance types $v$ Current generation $v$ Showilide Columns}

Currently selected: 12 micro (Variable ECUs, 1 vCPUs, $2.5 \mathrm{GHz}$, Intel Xeon Family, 1 GiB memory, EBS ont?

\begin{tabular}{|c|c|c|c|c|}
\hline & Family & Type & vCPUs (i) & Memory (GIB) \\
\hline (1) & General purpose & 12 nano & 1 & 0.5 \\
\hline a & General purpose & 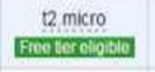 & 1 & 1 \\
\hline (1) & General purpose & 12.small & 1 & 2 \\
\hline 0 & General purpose & 12 medium & 2 & 4 \\
\hline 0 & Genera! purpose & t2large & 2 & 8 \\
\hline 0 & General purpose & $\mathrm{m} 4$ large & 2 & 8 \\
\hline
\end{tabular}

Gambar 10. Konfigurasi Hardware di Server Amazon EC2

Gambar 11 menunjukkan bahwa akses aplikasi telah berhasil setelah migrasi dari server fisik, dan virtual machine telah berjalan di server Amazon EC2. 

keseluruhan, migrasi dari server Amazon EC2 ke VMWARE terjadi kemunculan error atau defect software minor saat selesai migrasi, yang menyebabkan level interoperabilitas

SELAMAT DATANG

Menu

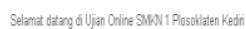
migrasi ini digolongkan ke level Peringatan di Tabel III.

Kemudian dari hasil pengujian terhadap aktivitas-aktivitas di Tabel II untuk migrasi Amazon EC2 ke VMWARE ini, terdapat 13 test case yang gagal dari keseluruhan pengujian, dengan total keseluruhan pengujian yang diujikan yaitu berjumlah 28 test case, sehingga tingkat interoperabilitas dari migrasi Amazon EC2 ke VMWARE dapat diperinci menjadi $13 / 28 * 100 \%=46.43 \%$.

\section{KESIMPULAN}

Setelah penelitian ini selesai dilakukan, peneliti dapat membuat beberapa kesimpulan di bawah ini:

Gambar 11. Keadaan Halaman Home Aplikasi Setelah Migrasi dari Physical Server

Sesuai aktivitas-aktivitas di Tabel II, ketika dilakukan pengujian fungsionalitas aplikasi di server VMWARE terdapat fungsionalitas yang berubah, yaitu hilangnya gambar banner website pada homepage saat diakses oleh client, dengan salah satu contohnya ditunjukkan pada Gambar 12 .
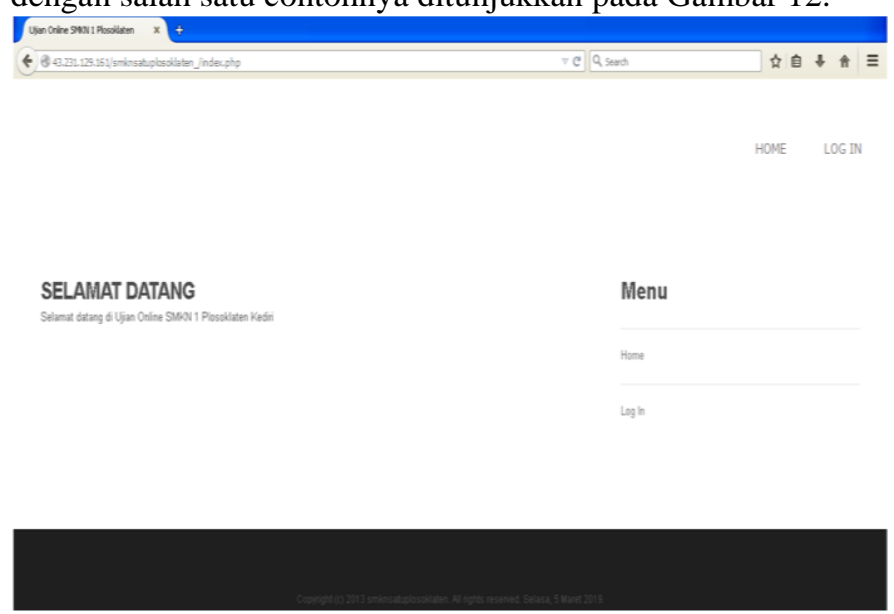

Gambar 12. Banner Website Halaman Home Aplikasi Tidak Muncul Setelah Migrasi ke Server VMWARE

\section{Hasil Evaluasi Keseluruhan}

Berdasarkan keseluruhan pengujian yang telah dilakukan, baik pengujian migrasi image virtual machine dan pengujian fungsionalitas aplikasi di masing-masing server migrasi, dapat ditentukan level interoperabilitasnya seperti perincian yang tertulis di Tabel III.

TABEL III

Hasil Evaluasi KesEluruhaN

\begin{tabular}{llll}
\hline \multicolumn{1}{c}{ Pengujian } & Berhasil & Peringatan & Gagal \\
\hline 1. Migrasi Sistem & & & \\
\hline Amazon EC2 ke VMWARE & Ya & Tidak & Tidak \\
\hline 2. Fungsionalitas Aplikasi & & & \\
\hline Amazon EC2 ke VMWARE & Tidak & Ya *) & Tidak \\
\hline
\end{tabular}

*) Banner website hilang.

A. Referensi yang dapat diberikan mengenai metode pengujian interoperabilitas migrasi sistem antar cloud adalah bahwa migrasi ini dapat diimplementasikan sesuai proses bisnis yang berjalan, yaitu melalui pengujian fungsionalitas aplikasi secara menyeluruh, sesuai aktivitasaktivitas yang dilakukan oleh para user ketika pengoperasian sistem aplikasi sedang dilakukan.

B. Salah satu layanan terbaik dalam migrasi di antara beberapa lingkungan cloud IaaS adalah migrasi dari Amazon EC2 ke VMWARE. Keuntungannya adalah berdasarkan kemudahan teknis migrasi yang menunjukkan bahwa migrasi dari Amazon EC2 ke VMWARE dapat dilakukan dengan lebih mudah daripada dipindah ke Penyedia Layanan Komputasi Awan yang lain, contoh : Microsoft Azure dan Proxmox.

C. Migrasi Cloud Computing dari Lingkungan Amazon EC2 ke VMWARE dapat mengatasi masalah ketergantungan terhadap beragamnya penyedia layanan cloud computing. Permasalahan ketergantungan ini merupakan suatu keadaan di mana pengguna suatu produk bergantung pada satu provider dan tidak dapat berpindah ke provider lain.

\section{UCAPAN TERIMA KASIH}

Pada kesempatan ini peneliti mengucapkan rasa terima kasih dan penghargaan kepada yang terhormat:

A. Prof. Dr. M. Suyanto, M.M. selaku Rektor Universitas AMIKOM Yogyakarta.

B. Dr. Prihandoko, M.IT. selaku Direktur Program S2 PJJ Konsorsium APTIKOM-AMIKOM, atas segala kebijaksanaan, perhatian, dan dorongan sehingga penulis dapat menyelesaikan studi S2 Teknik Informatika ini.

C. Dr. Kusrini, M.Kom. selaku Direktur Pascasarjana Universitas AMIKOM Yogyakarta.

D. Dr. Rizal Fathoni Aji, S.Kom., M.Kom. selaku Dosen Pembimbing dalam penelitian ini sekaligus mentor yang telah banyak membantu mengarahkan, membimbing, dan memberi motivasi sampai penelitian Tesis ini tersusun.

E. Para Dosen di PJJ Konsorsium APTIKOM-AMIKOM dan di Program Pascasarjana Universitas AMIKOM Yogyakarta, yang telah memberikan bekal ilmu dan pelayanan yang sangat bermanfaat. 
F. Rekan-rekan di Program Studi Magister Teknik Informatika Program S2 PJJ Konsorsium APTIKOMAMIKOM angkatan IV khususnya dan semua rekan mahasiswa Program Pascasarjana Universitas AMIKOM Yogyakarta, yang telah memberikan dukungan moral dan semangat untuk segera menyelesaikan studi saat penelitian ini sedang dilakukan.

G. Anggota Pengurus LPPM Jurnal Bangkit Indonesia di STT Indonesia Tanjungpinang, yang telah bersedia mempublikasikan hasil penelitian ini.

Semoga amal kebaikan dari berbagai pihak tersebut di atas mendapat pahala yang berlipat dari Allah SWT. Aamiin.

\section{REFERENSI}

[1] A. Lenk, G. Katsaros, M. Menzel, R. Skipp, J. Rake-Relevant, E Castro-Leon, Gopan V. P., TIOSA: Testing VM Interoperability at an OS and Application Level, Proceedings of IEEE International Conference on Cloud Engineering, Boston MA, 2014, pp. 245-252.

[2] M. Villary, I. Brandic, F. Tusa, Achieving Federated and SelfManageable Cloud Infrastructure:Theory and Practice, Business Science Reference(IGI Global), Hershey PA, 2012.

[3] J. Opera-Martin, S. Reza Justice, F. Tian, Critical Review of Vendor Lock-in and Its Impact on Adoption of Cloud computing, Proceedings of 2014 International Conference on Information Society (i-Society 2014), London, 2014, pp. 92-97.

[4] S. Dowell, A. Barreto, J.B. Michael, dan M. Shing, Cloud to Cloud Interoperability, Proceedings of 2011 6th International Conference on System of Systems Engineering, Albuquerque, 2011, hal. 258-263.

[5] B. Sosinky, Cloud Computing Bible, Wiley Publishing Inc., Indianapolis, 2011.

[6] Y. Jadeja, K. Modi, Cloud Computing - Concepts, Architecture and Challenges, Proceedings of 2012 International Conference on Computing, Electronics and Electrical Technologies [ICCEET], Kumaracoil, 2012, pp. 877-880.

[7] A. Strunk, W. Dargie, Does Live Migration of Virtual Machines cost Energy?, Proceedings of 2013 IEEE 27th International Conference on Advanced Information Networking and Applications, Barcelona, 2013 pp. 514-521.

[8] (2011) PCI Security Standard Council. [online]. Information Supplement: PCI DSS Virtualization Guidelines. Available https://www.pcisecuritystandards.org/documets/Virtualization_InfoSup p v2.pdf.

[9] (2013) Open Data Center Alliance. [online]. Virtual Machine (VM) Interoperability in a Hybrid Cloud Environmen Rev. 1.2. Available http://www.opendatacenteralliance.org.

[10] M.F. Gholami, F. Daneshgar, G. Low, G. Beydoun, Cloud migration process-A survey, evaluation framework, and open challenges, The Journal of Systems and Software 120, 2016, pp. 31-69. 